\title{
Biomonitoring of Heavy Metals: The Unexplored Role of Marine Sessile Taxa
}

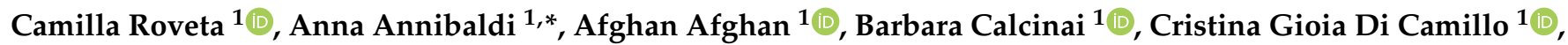 \\ Chiara Gregorin ${ }^{1,2}$, Silvia Illuminati ${ }^{1, * \mathbb{D}}$, Torcuato Pulido Mantas ${ }^{1}$, Cristina Truzzi ${ }^{1}$ and Stefania Puce ${ }^{1}$ \\ 1 Department of Life and Environment Sciences, Università Politecnica delle Marche, via Brecce Bianche, \\ 60131 Ancona, Italy; c.roveta@pm.univpm.it (C.R.); a.afghan@pm.univpm.it (A.A.); \\ b.calcinai@staff.univpm.it (B.C.); c.dicamillo@staff.univpm.it (C.G.D.C.); c.gregorin@pm.univpm.it (C.G.); \\ t.pulido@pm.univpm.it (T.P.M.); c.truzzi@staff.univpm.it (C.T.); s.puce@staff.univpm.it (S.P.) \\ 2 Integrative Marine Ecology Department, Stazione Zoologica Anton Dohrn, Villa Comunale, \\ 80121 Naples, Italy \\ * Correspondence: a.annibaldi@staff.univpm.it (A.A.); s.illuminati@staff.univpm.it (S.I.)
}

check for updates

Citation: Roveta, C.; Annibaldi, A.; Afghan, A.; Calcinai, B.; Di Camillo, C.G.; Gregorin, C.; Illuminati, S.;

Pulido Mantas, T.; Truzzi, C.; Puce,

S.et al. Biomonitoring of Heavy Metals: The Unexplored Role of Marine Sessile Taxa. Appl. Sci. 2021, 11, 580. https://doi.org/10.3390/ app11020580

Received: 17 December 2020

Accepted: 5 January 2021

Published: 8 January 2021

Publisher's Note: MDPI stays neutral with regard to jurisdictional clai$\mathrm{ms}$ in published maps and institutional affiliations.

Copyright: (C) 2021 by the authors. Licensee MDPI, Basel, Switzerland. This article is an open access article distributed under the terms and conditions of the Creative Commons Attribution (CC BY) license (https:// creativecommons.org/licenses/by/ $4.0 /)$.

\begin{abstract}
Coastal areas are known to receive significant anthropogenic inputs, mainly deriving from metropolitan areas, industries, and activities related to tourism. Among these inputs, some trace elements are listed as priority pollutants in the European Water Framework Directive, due to their ability to bioaccumulate in organisms. Many studies have been conducted on heavy metals (HMs) accumulation and on their possible effects on different edible marine species. While the most studied sessile organisms are bivalves, in the current review, we focus our attention on other sessile taxa (sponges, cnidarians, bryozoans, polychaetes, cirripeds, and tunicates), proposed as bioindicators in coastal shallow waters. Although their potential as bioindicator tools has been repeatedly highlighted in the literature, these organisms are still poorly investigated and considered for monitoring. In this context, we analyze the available literature about this topic, in order to summarize the current knowledge and identify possible applications of these organisms in a bioremediation scenario.
\end{abstract}

Keywords: zoobenthos; sentinel species; suspension feeders; water pollutants; bioaccumulation; heavy metals

\section{Introduction}

Marine coastal areas are among the most exploited and vulnerable ecosystems, constantly subjected to multiple anthropogenic pressures [1,2], due to the intensification of metropolitan areas, tourism, and industrial and agricultural activities [3,4]. These humaninduced perturbations cause in many cases the release of various contaminants, which can be transported in coastal waters through different pathways, as atmospheric depositions, rivers, industrial discharges, maritime traffic, or submarine groundwaters [3], representing important hazards for the ecosystem's health [1]. These contaminants principally include chemicals (e.g., heavy metals, polycyclic aromatic hydrocarbons (PAHs), pesticides, etc.) and fecal contaminants (e.g., Escherichia coli, total coliforms, and enterococci) [3]. Therefore, understanding the fate and distribution of contaminants in the sea and their origins is crucial to assess the ecological and chemical status of water and organisms and to implement management plans [2,5].

Heavy metals (HMs) are a problematic issue for marine ecosystems, ensuring that some of these elements and their derived compounds are listed in the European Water Framework Directive (WFD 2000/60/EC) as priority pollutants. Heavy metals are naturally occurring elements that can be found throughout the earth's crust. Nevertheless, anthropogenic activities (e.g., mining and smelting operations, industrial production and use, metal corrosion, atmospheric deposition, soil erosion of metal ions and leaching of heavy metals, and sediment resuspension) are primarily responsible for the environmental contamination and human exposure to these contaminants [6]. 
To date, a clear definition of the term "heavy metals" is not yet available. The term has been widely used in chemistry but no authority such as the International Union of Pure and Applied Chemistry (IUPAC) has ever defined it [7]. Even if its use is strongly discouraged, the term is increasingly used in the scientific literature especially in articles pertaining to multidisciplinary environmental issues [8]. On a chemical basis, the group of HMs includes all the transition elements (bloc $\mathrm{d}$ of the periodic table), the rare earth elements (the series of lanthanides and the series of actinides, including La and Ac themselves), and all the elements presenting the typical characteristics of metals (bloc p), together with some metalloids (Ge, As, and Te) and some nonmetals (Se) [7,9].

Some $\mathrm{HMs}$ (e.g., $\mathrm{Fe}, \mathrm{Cu}, \mathrm{Co}, \mathrm{Mn}$, and $\mathrm{Zn}$ ) are essential elements for organisms, playing key roles in the functioning of enzyme systems. However, high concentrations induce detrimental effects in organisms and in the environment. Other metals (e.g., $\mathrm{Al}, \mathrm{As}, \mathrm{Ba}, \mathrm{Bi}$, $\mathrm{Cd}, \mathrm{Pb}, \mathrm{Hg}, \mathrm{Ni}, \mathrm{Pt}$, and $\mathrm{Ag}$ ) have no specific biological functions and are considered as nonessential metals [10].

In the marine environment, heavy metals can be found in various chemo-physical forms (metal ions, hydrated ions, charged metal complexes, uncharged inorganic complexes, and organometallic complexes), each of them presenting different bioavailability, toxicity, bioaccumulation, mobility, and biodegradation rates [11]. All aquatic organisms can introduce and/or accumulate HMs in their tissues, taking them up from water or food, and the concentration of these elements can vary between taxonomic levels, from phyla down to species of the same genus [12]. Many studies have been carried out on the bioaccumulation and the effects of the different elements on marine organisms, but mainly on edible species (as bivalves, cephalopods, decapod crustaceans, and fish) e.g., [13,14]. However, other sessile organisms, e.g., polychaetes, tunicates, sponges, and barnacles, can be considered as suitable bioindicators for their physical and physiological characteristics $[15,16]$, and they have been recommended by many authors, e.g., [17-22], by the WFD and by the Marine Strategy Framework Directive (MSFD) [23]. Moreover, these organisms can represent an excellent functional tool since they do not only show detectable concentrations of trace elements $[18,24]$ but the presence of these chemicals in their tissues can also stimulate different physiological responses [25]. Therefore, they can be considered as useful biomonitors of HMs contamination, providing important information on the ecological and chemical status of an area.

The main aim of this systematic review is a spatiotemporal analysis of the literature on the bioaccumulation of HMs at global scale on six sessile marine taxa (Porifera, Cnidaria, Bryozoa, Polychaeta, Cirripedia, and Tunicata), considered as nonconventional biomonitors for chemicals pollution. The current work will provide a schematic summary of the current knowledge on the relationship between the selected taxa and HMs. It will identify possible applications of these organisms as bioremediation tools in contaminated environments, also accordingly to the European MSFD within the achievement of the Good Environmental Status (GES) (MSFD 2008/56/EC).

\section{Materials and Methods}

The present compilation is the result of an extensive bibliographic research on Elsevier's Scopus database (www.scopus.com), entering different keywords, "heavy metal" AND "taxa" and "heavy metal" AND "common name of the organism" (Figure 1), in the option "Article title, Abstract, Keywords," in all years until the cut-off date of 20 June 2020. The literature considered in this work includes journal articles and grey literature, as congress proceedings. Systematic reviews are not included by choice. All documents found with the aforementioned queries have been screened by reading titles and abstracts, excluding those not matching our criteria (Figure 1), and only the ones eligible for this study have been considered for the analysis. Duplicates, e.g., same documents found using different keywords, were counted as one. Since the Mediterranean province showed the highest number of documents on the topic, we conducted an additional manual research on the references reported in the found articles, in order to include possible documents on 
the area that could have been missed with the online search (Figure 1). A flow chart of the searching strategy and the eligibility process is given as Figure 1.

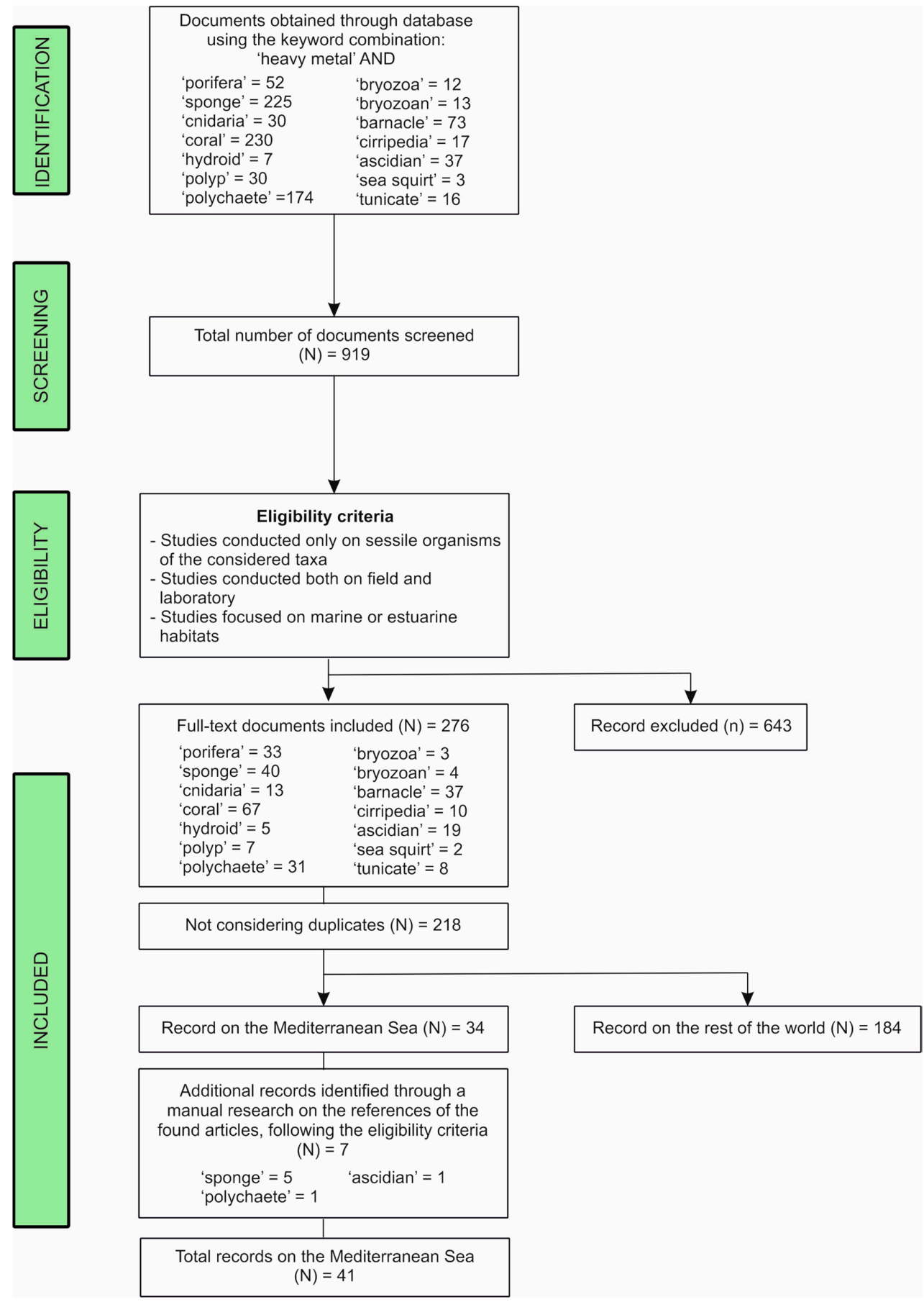

Figure 1. Flow chart illustrating the steps for obtaining documents about the study of heavy metals (HMs) on organisms from Scopus search engine and from the manual research.

Studies from the web-based and manual researches have been analyzed based on the taxa considered (Porifera, Cnidaria, Bryozoa, Polychaeta, Cirripedia, Tunicata), temporal distribution, marine realm of the sampling site(s), habitat (sea, estuarine), analyzed body part (cells and tissues, entire specimen, microbiome, skeleton), science field (biomonitoring, microbiology, physiology), HM(s), work setup (field, laboratory). Moreover, HMs considered in the documents have been divided in two categories, essential $(\mathrm{Co}, \mathrm{Cr}, \mathrm{Cu}, \mathrm{Fe}, \mathrm{Mn}$, 
Mo, Ni, Se, V, and Zn) and nonessential (Ag, Al, As, Bi, Cd, Ce, Cs, Eu, Ga, Hf, Hg, La, Lu, $\mathrm{Nb}, \mathrm{Pb}, \mathrm{Sb}, \mathrm{Sc}, \mathrm{Sn}, \mathrm{Te}, \mathrm{Th}, \mathrm{Ti}, \mathrm{U}, \mathrm{Y}$, and $\mathrm{Zr}$ ) elements following [26-28].

Documents related to the Mediterranean Sea province have been analyzed on the basis of the considered taxa (Porifera, Cnidaria, Polychaeta, Cirripedia, and Tunicata), temporal distribution, ecoregion of the sampling site(s), sampling depth(s), HM(s), considered order(s) per taxa. In all the analyses, every document could be included in one or more categories.

The analysis reported in Figure 2B was carried out following the bioregionalization of coastal and shelf areas proposed by Spalding et al. [29]. While, for the creation of the map of documents distribution in the Mediterranean Sea, geographic coordinates were used. In studies showing only a map of the sampling point(s), geographic coordinates were estimated from it. In the absence of a map, coordinates of the sampling point(s) were estimated using the information across the text, if available. When the given coordinates ended up in land, they were adjusted to the nearest coastal points.
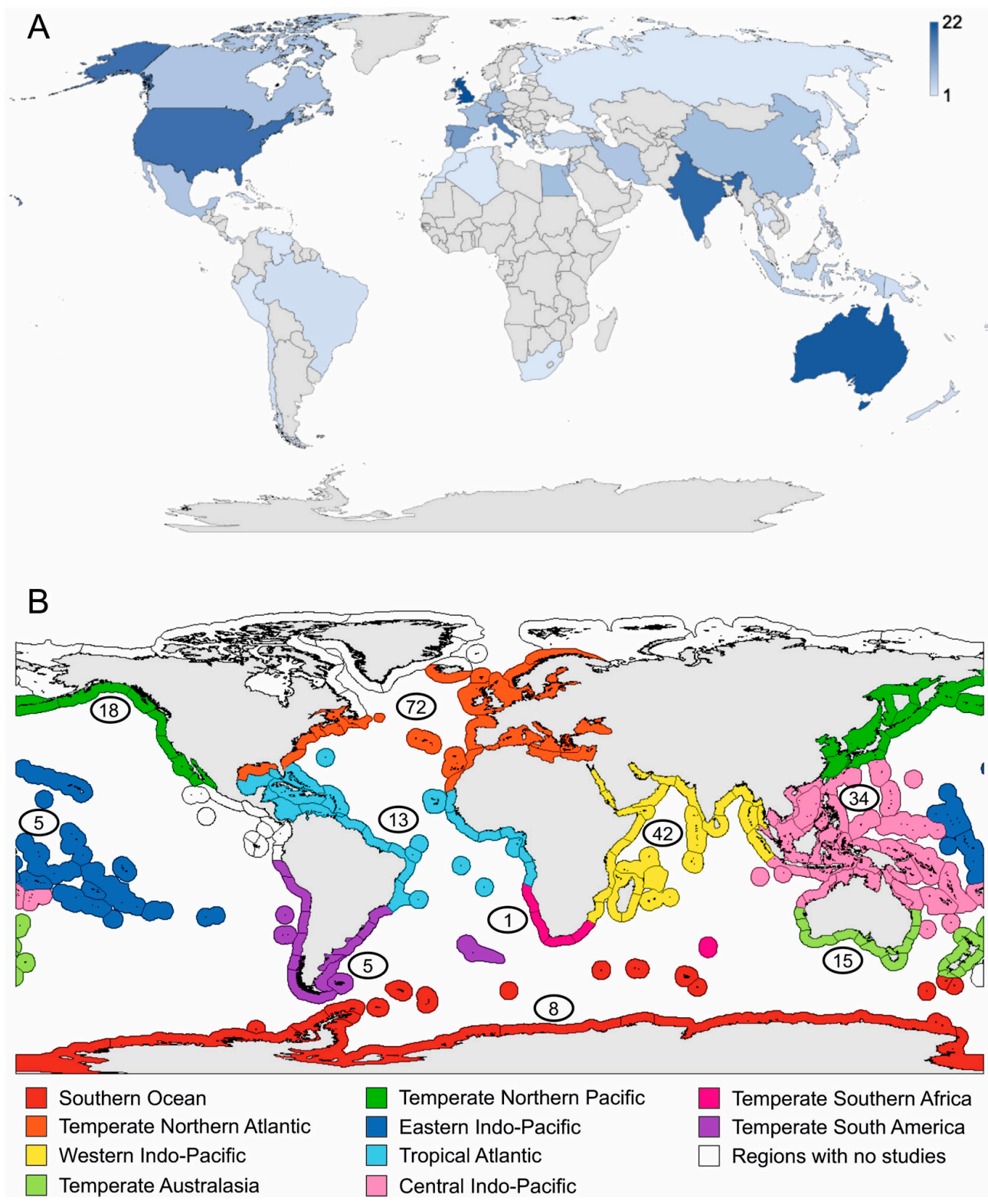

Figure 2. Map showing the number of documents per: (A) first authors' affiliation country and (B) marine realm. 
A list of works divided per taxa with all document's details (publication year, authors, title, DOI/Reference, source, first author affiliation country, realm of the sampling site, habitat, basic physicochemical parameters of water, taxa, application field, analyzed body part, data validation, $\mathrm{HM}(\mathrm{s})$, and work setup) is reported in the Supplementary Material as Table S1. The Supplementary Material also included a detailed list of documents (taxa, authors, publication year, marine ecoregion of the sampling site(s), latitude, longitude, depth, application field, order of the analyzed species, analyzed species, HM(s), concentration, and unit) on the Mediterranean Sea province as Table S2. In the case of HMs, concentrations were not reported along the text, they were estimated from graphs. Concentration units, if different, were standardized to make concentrations comparable between documents.

\section{Results}

\subsection{Literature Analysis at Global Scale}

A total of 919 documents (Figure 1), including duplicates, have been screened and analyzed by reading the title and abstract, using the aforementioned keywords. Those not following our eligibility criteria were removed (643), leading to 276 documents, spread among the six considered taxa (Figure 1). After excluding duplicates, the final number of analyzed works was 218 (Figure 1; Table S1).

Considering all the literature found, most of the works have been published from researches with an affiliation in the United Kingdom (22), Australia (21), India (19), the United States (18), and Italy (15) (Figure 2A). While in many eastern and northern European countries and various Asian and most of the African countries, only a few studies have been published (Figure 2A). Australia and the United Kingdom were the only two, out of 44 countries, where all six taxa were studied (Table S1). Regarding the sampling area, most of the studies were carried out with organisms collected in the Temperate Northern Atlantic (32.0\%) and the Western (18.7\%) and Central (15.1\%) Indo-Pacific marine realms (Figure 2B). Inside the Temperate Northern Atlantic realm, the Mediterranean Sea province showed the highest number of documents (34). All the other studies are scattered among the other marine realms, with only one work in the Temperate Southern Africa and a total absence of studies in the Tropical Eastern Pacific and the Arctic (Figure 2B). Up to the 12.8\% of the total documents have not been taken into account for the creation of Figure $2 \mathrm{~B}$ in as much as 12 works did not give any information about the sampling site(s), 12 considered marine organisms breed in aquarium, and 5 regarded organisms collected on hydrothermal vents located in areas not included in the division proposed by Spalding et al. [29] (Table S1). Most of the studies included species collected in the marine environment $(92.8 \%)$, and only an $8.0 \%$ focused on estuarine organisms (Table S1).

The heatmap presented as Figure 3A showed that the first document, found using the query "heavy metal" AND "ascidian," was published before 1970 (1956, see Table $\mathrm{S} 1$ for citation). After this publication, for all taxa except Bryozoans, for which the first publication is registered in the decade 1991-2000 (1992, see Table S1 for citation), no works could be found until 1971-1980 (Figure 3A). In general, there is an upward trend in the number of documents through time, for almost all the taxa, while for Cirripedia, it is possible to identify a peak in 1991-2000 and a decrease in documents in the following decades (Figure 3A). The taxa of Cnidaria shows the highest number of works in almost all the decades, with the $37.0 \%$ of the publications, resulting the most studied group for HMs, followed by Porifera (18.5\%), a group presenting a great increase in documents starting from 2001 (Figure 3A). 

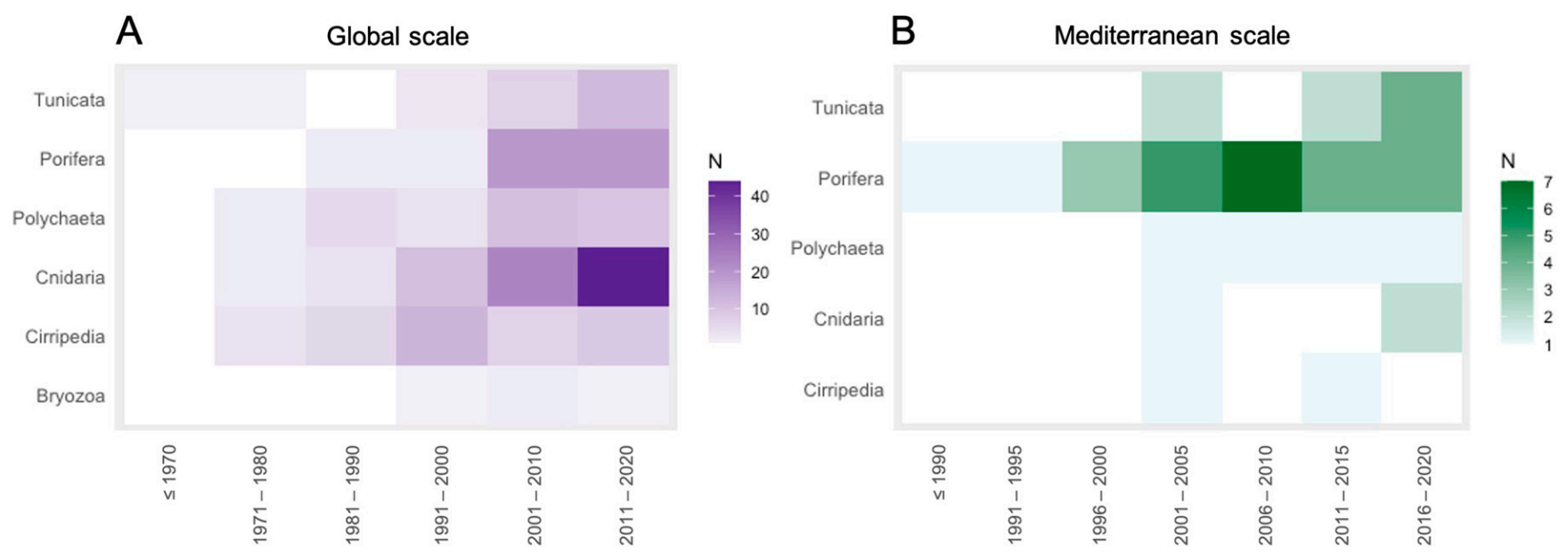

Figure 3. Number of documents per: (A) decade, at global-scale and (B) 5-year period, at Mediterranean-scale.

From the literature collection, it was evident that most of the documents analyzed both essential and nonessential elements (72.0\%), in particular $\mathrm{Cd}$ (146), $\mathrm{Cu}(172), \mathrm{Pb}(110)$, and $\mathrm{Zn}(142)$, while the $19.1 \%$ analyzed only essential elements and the $8.9 \%$ only nonessential ones (Table S1).

Organisms belonging to the six considered taxa have been mainly collected for biomonitoring analysis (Figure 4A), aiming to measure HMs concentrations in organisms and tissues. In particular, a significant proportion of documents in each taxon, for their analysis, processed the entire specimen, followed by the skeleton, especially in the Cnidaria group (Figure 4B). In fact, among the 43 documents on skeletal analysis, 36 examined the one of cnidarians (Table S1). Figure 4A showed also a total absence of physiological studies on Bryozoa, while only 2 have been conducted on Cirripedia (see Table S1 for citations). The remaining documents are spread among the other four taxa (Figure 4A). Works on microbiology represent a small component (15 documents) of the total, most of them (7) on Porifera (Figure 4A). A comparable situation can be observed for studies on cells and tissues and the microbiome, which have not been taken into account very frequently (Figure 4B).

The $59.1 \%$ of documents processed samples after their collection on the field (Figure 5A), especially for Cirripedia and Cnidaria (Figure $5 B$ ), while the $36.0 \%$ conducted laboratory experiments (Figure 5A). Among all taxa, organisms mainly belonging to the Cnidaria group have been used for this aim (Figure 5B). Only a small percentage (4.9\%) of documents regarded studies in which collected organisms have been processed immediately to analyze a possible bioaccumulation of HMs and they have been bred to conduct laboratory experiments on the possible physiological effects of elements (Figure 5A). Apart from Cirripedia and Cnidaria, all the other taxa showed studies conducted with this work set up (Figure 5B). 

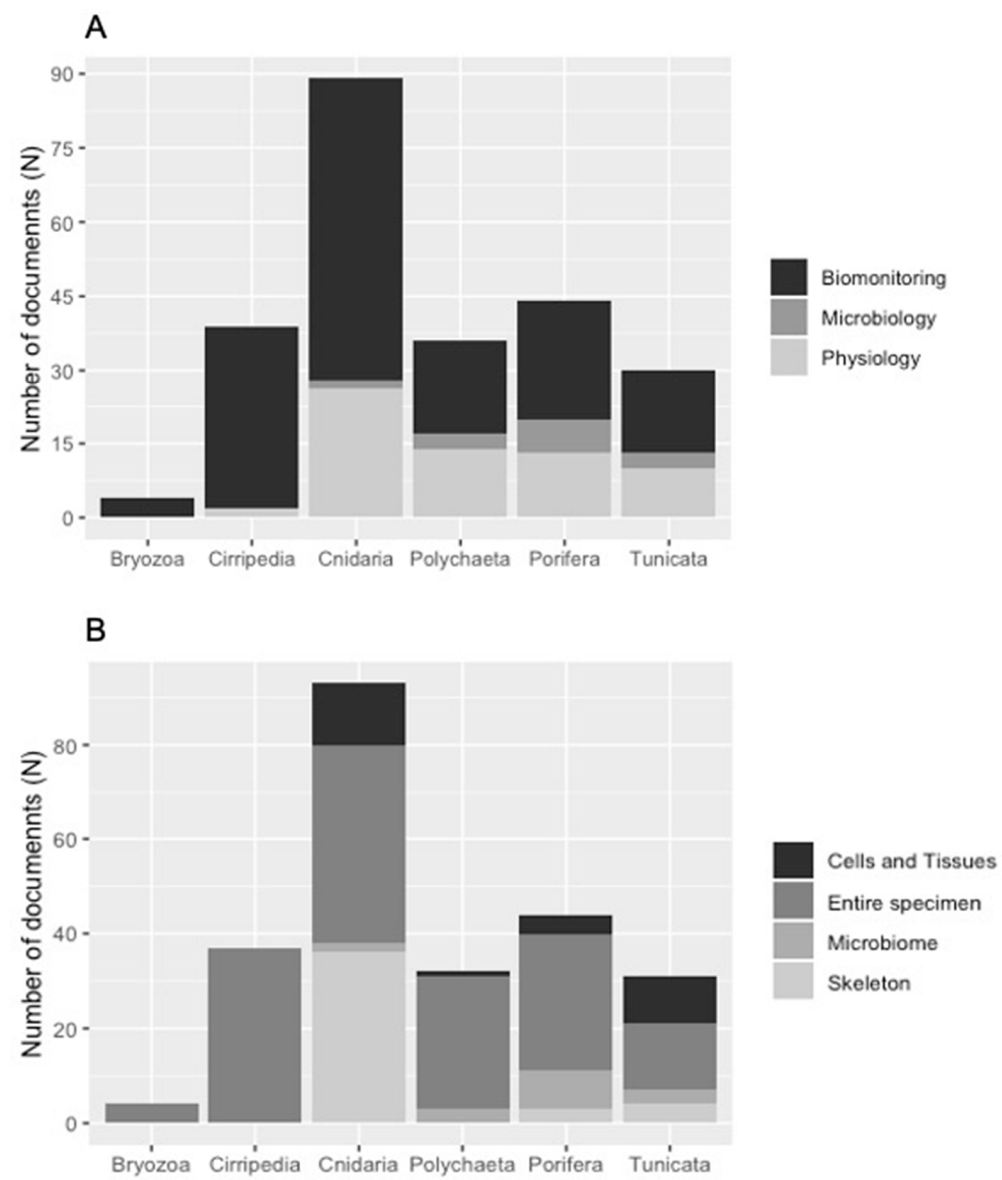

Figure 4. Number of documents per: (A) science field and (B) analyzed body part.

A

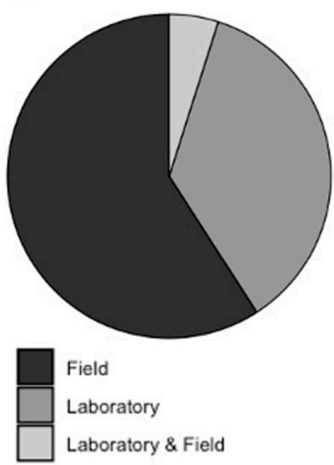

B
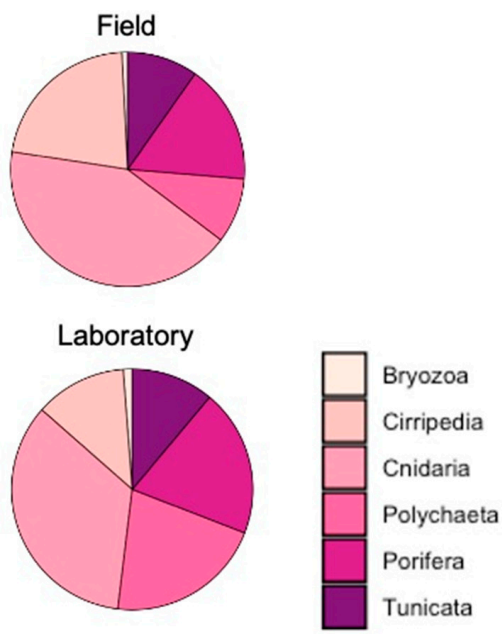

Laboratory \& Field

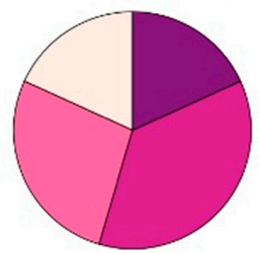

Figure 5. Percentage of documents per: (A) work setup and (B) taxa in each work setup. 


\subsection{Literature Analysis Focused on the Mediterranean Sea Province}

The literature analysis on documents found within the Elsevier's Scopus database led to the record of 34 works on organisms collected in the Mediterranean Sea province. The manual research carried out on the references reported in these works led to the addition of seven documents. The total 41 documents (Figure 1) regarded 5 of the 6 considered taxa: Porifera (24), Cnidaria (3), Polychaeta (4), Cirripedia (2), and Tunicata (8) (Table S2).

Among all documents, only one work regarding Porifera was published before 1991 (1990, see reference in Table S1) (Figure 3B). The temporal distribution of documents showed how Porifera were considered in every 5-year period, with a peak in 2006-2010 (Figure 3B). Polychaeta were included in a constant number of works from 2001 to 2005, while for Tunicata, there is an increment of documents during time (Figure 3B). On the other hand, the low number of works on Cnidaria and Cirripedia is scattered through the different 5-year periods, from 2001 to 2005 till today (Figure 3B).

Inside the basin, most of the studies collected organisms in the Western Mediterranean ecoregion (22), mainly along the French and Spanish coasts (Figure 6; Table S2), followed by the Adriatic Sea (7), the Ionian Sea (6), the Levantine Sea (4), and the Aegean Sea (2) (Table S2). Figure 6 shows that most of the Porifera have been collected in the Western Mediterranean, while almost all studies on Tunicata and all on Cirripedia are referred to organisms collected in the Levantine and the Aegean Sea. Two-third of documents, moreover, gave information on the sampling depth (Figure 7). Most of the organisms were collected between 0 and $5 \mathrm{~m}$ depth, while Porifera is the only taxon collected at all the considered depth ranges (Figure 7).

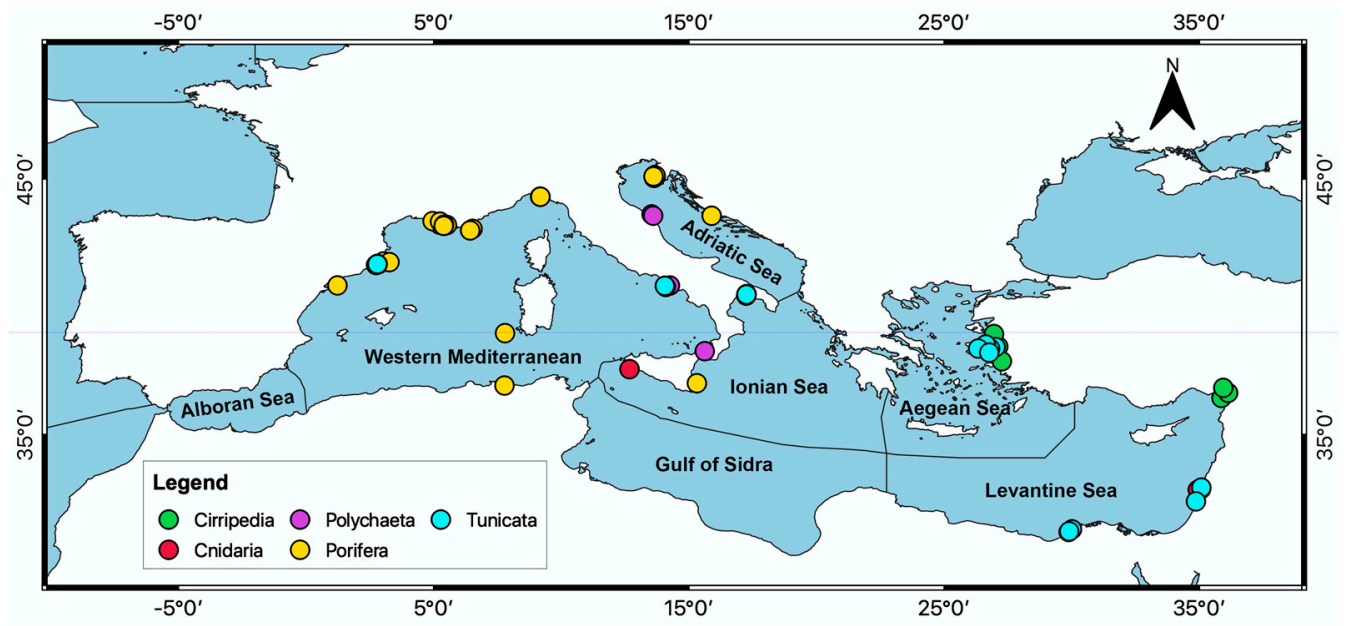

Figure 6. Map of the distribution of documents per taxa in each ecoregion of the Mediterranean Sea.
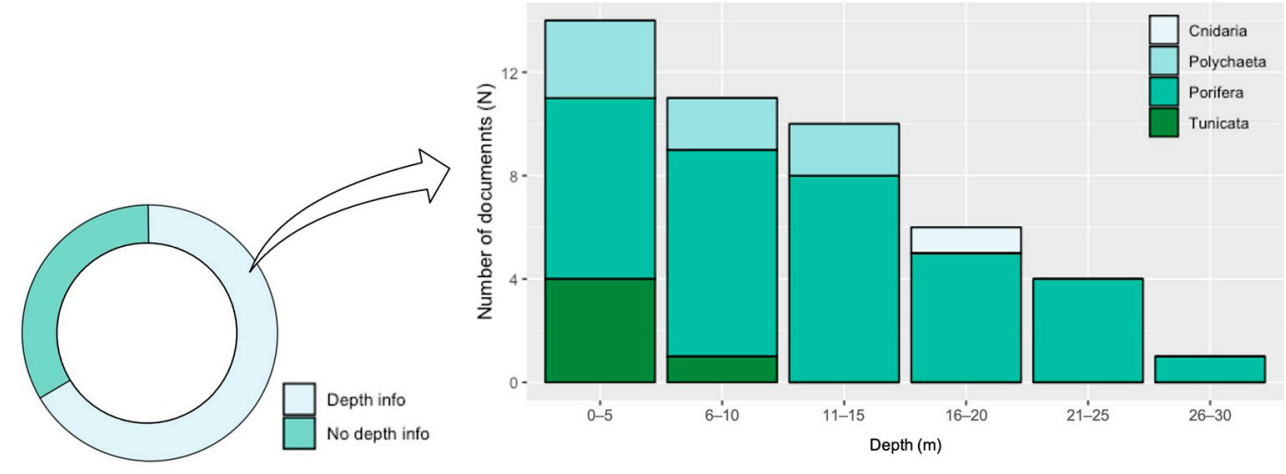

Figure 7. Donut chart of the percentage of documents giving information of the sampled depth(s) (left), and number of documents per taxa per depth range (right). 
Most of the documents studied the role of organisms as bioindicators (28) especially of $\mathrm{Cu}(28), \mathrm{Pb}(23)$, and $\mathrm{Cd}$ (20) contamination. Fourteen works explored the main effects of $\mathrm{Cd}(10)$ and $\mathrm{Cu}(9)$ on the collected species (Table S2), while one paper highlighted the tolerance of the microbiota extracted from polychaetes to $\mathrm{Cd}, \mathrm{Cu}$, and $\mathrm{Zn}$ (see Table S1 for citation).

Since Porifera resulted to be the most studied taxa, we considered this group for further considerations. Species studied belong to 11 orders of sponges (Table S2), and Dictyoceratida is undoubtedly the one to which most of works on biomonitoring are related. These organisms showed Cd concentrations ranging between 0.2 and $1.60 \mathrm{mg} \cdot \mathrm{kg}-1 \mathrm{~d}$.w., $\mathrm{Cu}$ between 22 and $300 \mathrm{mg} \cdot \mathrm{kg}-1 \mathrm{~d} . w$. , and $\mathrm{Pb}$ between 0.1 and $90 \mathrm{mg} \cdot \mathrm{kg}-1 \mathrm{~d} . \mathrm{w}$. (Table S2). Dictyoceratida has not been investigated for possible effects given by the presence of trace elements, but orders as Poecilosclerida and Scopalinida were considered more suitable for physiological studies and mainly on Cd and Cu (Table S2).

\section{Discussion}

At present, the sessile taxa considered in this study (Porifera, Cnidaria, Bryozoa, Polychaeta, Cirripedia, and Tunicata) are still little used as biomonitors compared with other groups, despite the fact that their potential application has been highlighted repeatedly during time [12,23], with an increasing annual trend in the last years. For example, searching on Scopus database using the keywords "heavy metal" AND "bivalve" or "heavy metal" AND "fish," without conducting the screening, 1148 and 6800 documents were obtained, respectively, more than all the works screened in our research, conducted using many keywords. In fact, the vast majority of the studies on the topic referred to organisms representing food resources for human consumption, which do not have to exceed specific levels, established by Community legislation or other relevant standards [23,30]. Another factor to take into account is that the considered taxa are not of the same economic importance as bivalves or fish, even though the economic role covered by some of them (e.g., sponges) is more and more often highlighted by the scientific community [31]. Nonetheless, looking at the physical and physiological characteristics a bioindicator should present (see Butler et al. [15] and Haug et al. [16]), these groups fit in many of the listed features. In fact: (i) with the exception of some cnidarians and polychaetes, they are exclusively sessile; (ii) most of them are active filter-feeders; (iii) they present a global distribution, therefore they can be collected and used for this purpose all around the globe, even at the Poles; (iv) these taxa comprehend modular organisms [32], therefore the collection of small portions does not affect their survival and they can rapidly regenerate; (v) some of them present also a gregarious behavior [33-37], allowing to sample just a part of a population and to observe possible changes on long-term monitoring.

From our review, it is clear that, at a global scale, studies are not equally distributed among marine regions [29], with most studies focused the Mediterranean Sea province [29], probably due to its nature of being a semienclosed basin [38], and thus more subjected to anthropogenic stress and pollution [39], as the one caused by HMs (see Table 1 from Danovaro [40], for quantities released annually, and Table 1 from Tovar-Sánchez et al. [41], for the concentration in the Mediterranean water). The basin, moreover, is subjected to the European legislation (e.g., MSFD 2008/56/EC), which suggests biological indicators (e.g., sponges and cnidarians) as potential tools to monitor the environmental status of coastal areas. Therefore, researchers could be more addressed to use unconventional organisms in their biomonitoring studies. However, also in the Mediterranean basin, there is a bias in the studies distribution, since research activities mainly focused on the Western Mediterranean ecoregion (22) [29], while the others are interested only by a low number of studies. This condition should be explained with the affiliation of the researchers studying the topic, which are mostly present in countries facing the Western Mediterranean ecoregion. Moreover, most of studies are limited to the most accessible shallow waters, mainly investigated by scuba diving. 
Another strong bias highlighted by the present work is the difference in the number of documents per taxon, most of them concerning Cnidaria (37\%) and Porifera (18.5\%). Considered cnidarians are especially from tropical areas (Table S1), in which studies principally investigated the concentrations of HMs particularly in the hard skeleton of many scleractinian corals. Their skeleton is, in fact, characterized by the presence of growth bands, used in the determination of coral's age [42,43], and as a proxy of ocean responses to environmental factors, as temperature and salinity [44,45], and also contaminants, such as heavy metals [46,47], hydrocarbons [48], and pesticides [49]. This peculiarity makes the coral skeleton an important biomonitoring tool for marine pollution, allowing to analyze and detect possible variations in the concentrations of HMs over different time periods. However, together with scleractinians, other groups of cnidarians, e.g., octocorals and stylasterids, showed the presence of growth bands in their skeletons [50,51], making these taxa additional organisms suitable for biomonitoring studies.

Regarding the other well-studied group, Porifera have been mainly collected in the Temperate Northern Atlantic realm [29]. Especially interesting are the few studies analyzing the role of their associated bacteria [52-58]. Many sponges, in fact, are characterized by the presence of complex communities of microorganisms composing the associated microbiota, being named "bacteriosponges" or "high microbial abundance sponges" [59]. Since the microbiota can contribute up to $40 \%$ of sponge biomass and cover a fundamental role in their secondary metabolism [60,61], it has been suggested that it can actively participate in the bioaccumulation process. Many bacteria isolated from sponges, e.g., Fasciospongia cavernosa, have been found to be resistant to different antibiotics and pollutants, including Persistent Organic Pollutants (POPs) and various heavy metals, as $\mathrm{Cu}, \mathrm{Pb}$, $\mathrm{Co}, \mathrm{Cd}, \mathrm{Zn}, \mathrm{Ni}$, and $\mathrm{Hg}$ together with their organic compounds [55]. Different researches showed how also the bacteria associated with polychaetes and ascidians can be important in the sequestration of HMs from water [62-67]; therefore, increasing study of the effective role of the microbiota is necessary to fully understand the dynamics of the process. Besides, we want to stress the importance of works on the possible negative physiological effects of HMs in organisms (e.g., apoptosis of sponge tissues, bleaching in corals, decreasing of sperm density in polychaetes, etc.) [68-70], but also the "positive" consequences that HMs can trigger, e.g., in the moon jellyfish Aurelia spp., which polyps were observed to increase their asexual reproduction if exposed to $\mathrm{Ag}$ and $\mathrm{Hg}[4,71]$. However, what we call a "positive" response can have severe environmental consequences. Referring to the example of Aurelia spp., an increase in the asexual reproduction can be followed by increase in polyp strobilation and ephyra release and, thus, intense jellyfish blooms [72], with multiple ecological and socio-economic consequences on human health, marine trophic chains, fishery, and aquaculture [73,74]. Moreover, an increase in this kind of studies will help to identify different physiological traits known as "biomarkers." Biomarkers are biological responses of suitable sentinel species to pollutants, which can act as early-warning tools able to detect pollutant-induced stress syndromes in organisms before the occurrence of severe habitat and communities' alterations [75].

From our review emerged clearly that the most studied $\mathrm{HMs}$ have been $\mathrm{Cd}, \mathrm{Cu}, \mathrm{Pb}$, and $\mathrm{Zn}$, both due to their natural toxicity (Cd and Pb) (WFD 2000/60/EC) and both for being used by organisms as micronutrients ( $\mathrm{Cu}$ and $\mathrm{Zn}$ ). In fact, essential elements can be considered HMs since they can become toxic, for an organism, above specific thresholds [28], as it was observed, e.g., in Aurelia aurita polyps [71] or in the sponge Crambe crambe [76]. Many groups of invertebrates are known to synthetize metallothioneins or metallothioneinlike proteins, including the taxa considered in this review [77-80], except for Cnidaria and Bryozoa, for which there is still no information available [81-83]. Metallothioneins are cysteine-rich metal-binding proteins, which can sequester metals, being involved in metal resistance and in the detoxification processes [82]. If the detoxification mechanism is not overwhelmed, organisms can increase body metal concentrations without showing toxic effects or signs of suffering. However, if in the environment metal concentrations are elevated, the mechanism overwhelms and metals can bind to sensitive intracellular targets, 
inducing toxicity [84]. Therefore, to understand the thresholds not to be overcome, for both essential and nonessential elements, results fundamental to set general concentration limits focused on organism wellness, since by now, the actual low limits for HMs concern only edible species (Directive 2002/32/EC) and many are referred to human health [30].

Another important issue emerging from our bibliographic analysis was the lack of a standardization of presented data. First of all, almost half of the studies (generally written in the last century) did not show any information about the quality assurance (Certified Reference Material (CRM), recovery of standard addition, etc.) and, even though the $54 \%$ presented quality information, they were provided in an unclear way (no table of data and explanation of the reference material) or inappropriate material has been used (Table S1). In addition, only about the $15 \%$ analyzed the physicochemical parameters of water (e.g., pH, conductivity, alkalinity, organic matter, etc.) (Table S1), factors which could influence the speciation of HMs in the marine environment [85] and, thus, modify their bioavailability [11]. Different concentration orders and units are also given, making difficult the data management and the intercomparison among studies. Most of documents expressed data in dry weight (d.w.) while some others expressed results in wet weight (w.w.). If data presented in w.w. do not also provide the water concentration in samples, they are not comparable with those expressed in d.w. These issues arouse the attention of the scientific community since the 1970s [86], and the suggestion for the creation of "quality assurance" protocols for data comparison was given repeatedly in past decades [75,87]. Examples are the MED POL Mediterranean Sea Biomonitoring Programme [88] and the Pollution Effect Network (PEN) [75]. However, these activities did not pursue until today, while the intercomparison problem persists.

\section{Conclusions and Future Perspectives}

The results of our review showed a growing interest by the scientific community in the identification of sessile taxa as nonconventional bioindicators of HMs. The increasing interest is mainly linked to the higher awareness of researchers to metals contamination in the marine environment and to the international legislations, which are more and more focused on the role of these taxa as fundamental monitors of environmental pollution. Different studies suggested that some sessile organisms can be used also in the bioremediation processes, thanks to their characteristics and the part played by the associated microbiota (bacteria and fungi). This is particularly true for sponges, cnidarians, polychaetes, bivalves, and tunicates $[60,64,89-91]$. The application of vagile organisms as bioremediation and biomonitoring tools (as fish, cephalopods, or decapods crustaceans) results instead more difficult, since they are not sessile and cannot detect the actual values of a single location. In addition, even if the present work focused only on marine species, some of the considered taxa (Porifera, Cnidaria, and Bryozoa) also includes freshwater species. Therefore, these organisms can be applied as useful tools also near inland farms, industries, and plantations, as it is already done for freshwater bivalves [92].

Nonetheless, researchers should also focus their attention in identifying model organisms, which proved to be more suitable as bioindicators or bioremediation tools compared to other species of the same taxa.

These research activities cannot exclude the consultations of specialized taxonomists, since (1) species belonging to the same genus can bioaccumulate different concentration of HMs [12] or can present different responses if subjected to the same metal (see Figure 1 from Viarengo et al. [75] for the different physiological responses of Mytilus galloprovincialis); (2) some species considered by the literature revised for this study (e.g., Geodia cynodium, Spongia (Spongia) lamella, and S. (S.) officinalis) (see Tables S1 and S2 for citations) are included in the Annex II of the SPA/BIO Protocol of Barcelona Convention and, therefore, subjected to protection, due to their status of "threatened" species [93].

Our work highlighted many research gaps, but two aspects need special attention. As future perspectives, we recommend increasing sampling and collection efforts and widening the geographic and bathymetric distributions of the studies not only in the 
Mediterranean Sea but also in the other marine realms, provinces and ecoregions, especially in the less investigated ones, integrating the results with the studies currently available. Moreover, data standardization is still a big issue in the field, therefore, we suggest facing the problem again, reopening old programs (e.g., MED POL and PEN) or crating new ones with new possible protocols to standardize methods, validation, analysis, and data presentation.

Supplementary Materials: The following are available online at https://www.mdpi.com/2076-341 7/11/2/580/s1, Table S1: List of works divided per taxa with all document's details, Table S2: List of documents on the Mediterranean Sea province.

Author Contributions: Conceptualization, A.A. (Anna Annibaldi) and S.P.; methodology, A.A. (Anna Annibaldi), C.R. and S.P.; software, C.R., C.G., T.P.M., A.A. (Afghan Afghan); formal analysis, C.R.; investigation, C.R.; data curation, C.R. and A.A. (Anna Annibaldi); writing-original draft preparation, C.R., A.A. (Anna Annibaldi) and S.I.; writing—review and editing, all authors; project administration, A.A. (Anna Annibaldi) and S.P.; funding acquisition, S.P. All authors have read and agreed to the published version of the manuscript.

Funding: This study has been conducted with the financial support of PADI FOUNDATION (grant number \#32694) and the Università Politecnica delle Marche (RSA-Ricerca Scientifica di Ateneo).

Institutional Review Board Statement: Not applicable.

Informed Consent Statement: Not applicable.

Data Availability Statement: Data is contained within the article and supplementary material.

Acknowledgments: Authors are thankful to Carlo Cerrano for his precious suggestions, which helped to improve our work.

Conflicts of Interest: The authors declare they have no conflict of interest.

\section{References}

1. Caeiro, S.; Costa, M.H.; Ramos, T.B.; Fernandes, F.; Silveira, N.; Coimbra, A.; Medeiros, G.; Painho, M. Assessing heavy metal contamination in Sado Estuary sediment: An index analysis approach. Ecol. Indic. 2005, 5, 151-169. [CrossRef]

2. Orlandi, L.; Bentivoglio, F.; Carlino, P.; Calizza, E.; Rossi, D.; Costantini, M.L.; Rossi, L. $\delta^{15}$ N variation in Ulva lactuca as a proxy for anthropogenic nitrogen inputs in coastal areas of Gulf of Gaeta (Mediterranean Sea). Mar. Pollut. Bull. 2014, 84, 76-82. [CrossRef]

3. Tedetti, M.; Guigue, C.; Goutx, M. Utilization of a submersible UV fluorometer for monitoring anthropogenic inputs in the Mediterranean coastal waters. Mar. Pollut. Bull. 2010, 60, 350-362. [CrossRef] [PubMed]

4. Roveta, C.; Annibaldi, A.; Vagnoni, F.; Mantas, T.P.; Domenichelli, F.; Gridelli, S.; Puce, S. Short-term effects of environmental factors on the asexual reproduction of Aurelia sp. polyps. Chem. Ecol. 2020, 36, 486-492. [CrossRef]

5. Illuminati, S.; Annibaldi, A.; Truzzi, C.; Scarponi, G. Heavy metal distribution in organic and siliceous marine sponge tissues measured by square wave anodic stripping voltammetry. Mar. Pollut. Bull. 2016, 111, 476-482. [CrossRef] [PubMed]

6. Carnevali, O.; Benedetti, M.; Beolchini, F.; Dell'Anno, A.; Fattorini, D.; Gorbi, S.; Illuminati, S.; Maradonna, F.; Scarponi, G.; Regoli, F. New Insights for Early Warning and Countermeasures to Aquatic Pollution. In The First Outstanding 50 Years of "Università Politecnica delle Marche"; Longhi, S., Monteriù, A., Freddi, A., Aquilanti, L., Ceravolo, M.G., Carnelavi., O., Giordano, M., Moroncini, G., Eds.; Springer: Cham, Switzerland, 2020; pp. 431-455. [CrossRef]

7. Duffus, J.H. Heavy metals-a meaningless term? Pure Appl. Chem. 2002, 74, 793-807. [CrossRef]

8. Pourret, O.; Hursthouse, A. It's Time to Replace the Term "Heavy Metals" with "Potentially Toxic Elements" When Reporting Environmental Research. Int. J. Environ. Res. Public. Health 2019, 16, 4446. [CrossRef] [PubMed]

9. Appenroth, K.-J. What are "heavy metals" in Plant Sciences? Acta Physiol. Plant. 2010, 32, 615-619. [CrossRef]

10. Chang, L.W.; Magos, L.; Suzuki, T. Toxicology of Metals; CRC Press: Boca Raton, FL, USA, 1996.

11. Simkiss, K.; Taylor, M.G. Transport of metals across membranes. In Metal Speciation and Bioavailability in Aquatic Systems; Tessier, A., Turner, D., Eds.; John Wiley \& Sons Ltd.: Chichester, UK, 1995; pp. 1-44.

12. Rainbow, P.S. Trace metal concentrations in aquatic invertebrates: Why and so what? Environ. Pollut. 2002, 120, 497-507. [CrossRef]

13. Annibaldi, A.; Truzzi, C.; Carnevali, O.; Pignalosa, P.; Api, M.; Scarponi, G.; Illuminati, S. Determination of Hg in farmed and wild atlantic bluefin tuna (Thunnus thynnus L.) muscle. Molecules 2019, 24, 1273. [CrossRef]

14. Cammilleri, G.; Galluzzo, P.; Pulvirenti, A.; Giangrosso, I.E.; Lo Dico, G.M.; Montana, G.; Lampisi, N.; Mobilia, M.A.; Lastra, A.; Vazzana, M.; et al. Toxic mineral elements in Mytilus galloprovincialis from Sicilian coasts (Southern Italy). Nat. Prod. Res. 2020, 34, 177-182. [CrossRef] [PubMed] 
15. Butler, P.A.; Andren, L.; Bonde, G.J.; Jernelov, A.; Reisch, D.J. Monitoring organisms. In Food and Agricultural Organization Technical Conference on Marine Pollution and its Effects on Living Resources and Fishing, Rome, 1970. Supplement 1: Methods of Detection, Measurement and Monitoring of Pollutants in the Marine Environment; Ruivo, M., Ed.; Fishing News Ltd.: London, UK, 1971; pp. 101-112.

16. Haug, A.; Melsom, S.; Omang, S. Estimation of heavy metal pollution in two Norwegian fjord areas by analysis of the brown alga Ascophyllum nodosum. Environ. Pollut. 1974, 7, 179-192. [CrossRef]

17. McKenzie, L.A.; Brooks, R.; Johnston, E.L. Heritable pollution tolerance in a marine invader. Environ. Res. 2011, 111, 926-932. [CrossRef] [PubMed]

18. Batista, D.; Muricy, G.; Rocha, R.C.; Miekeley, N.F. Marine sponges with contrasting life histories can be complementary biomonitors of heavy metal pollution in coastal ecosystems. Environ. Sci. Pollut. Res. 2014, 21, 5785-5794. [CrossRef]

19. Colozza, N.; Gravina, M.F.; Amendola, L.; Rosati, M.; Akretche, D.E.; Moscone, D.; Arduini, F. A miniaturized bismuth-based sensor to evaluate the marine organism Styela plicata bioremediation capacity toward heavy metal polluted seawater. Sci. Total Environ. 2017, 584, 692-700. [CrossRef]

20. Giangrande, A.; Licciano, M.; Del Pasqua, M.; Fanizzi, F.P.; Migoni, D.; Stabili, L. Heavy metals in five Sabellidae species (Annelida, Polychaeta): Ecological implications. Environ. Sci. Pollut. R. 2017, 24, 3759-3768. [CrossRef]

21. Jupp, B.P.; Fowler, S.W.; Dobretsov, S.; van der Wiele, H.; Al-Ghafri, A. Assessment of heavy metal and petroleum hydrocarbon contamination in the Sultanate of Oman with emphasis on harbours, marinas, terminals and ports. Mar. Pollut. Bull. 2017, 121, 260-273. [CrossRef]

22. Souri, A.; Niyogi, S.; Naji, A. Distribution, source apportionment, bioavailability and ecological risks of metals in reef sediments and corals of the Persian Gulf (Iran): Khark Island, Chirouyeh, and Hendorabi Island. Mar. Pollut. Bull. 2019, $149,110654$. [CrossRef]

23. Haynes, T.; Bell, J.; Saunders, G.; Irving, R.; Williams, J.; Bell, G. Marine Strategy Framework Directive Shallow Sublittoral Rock Indicators for Fragile Sponge and Anthozoan Assemblages Part 1: Developing Proposals for Potential Indicators; JNCC Report No. 524; Nature Bureau and Environment Systems Ltd. for JNCC: Peterborough, UK, 2014; p. 85.

24. Truzzi, C.; Annibaldi, A.; Illuminati, S.; Bassotti, E.; Scarponi, G. Square-wave anodic-stripping voltammetric determination of $\mathrm{Cd}, \mathrm{Pb}$, and $\mathrm{Cu}$ in a hydrofluoric acid solution of siliceous spicules of marine sponges (from the Ligurian Sea, Italy, and the Ross Sea, Antarctica). Anal. Bioanal. Chem. 2008, 392, 247-262. [CrossRef]

25. Ledda, F.D.; Ramoino, P.; Ravera, S.; Perino, E.; Bianchini, P.; Diaspro, A.; Gallus, L.; Pronzato, R.; Manconi, R. Tubulin posttranslational modifications induced by cadmium in the sponge Clathrina clathrus. Aquat. Toxicol. 2013, 140, 98-105. [CrossRef]

26. Vincent, J.B. New evidence against chromium as an essential trace element. J. Nutr. 2017, 147, 2212-2219. [CrossRef] [PubMed]

27. Sobolev, N.; Aksenov, A.; Sorokina, T.; Chashchin, V.; Ellingsen, D.G.; Nieboer, E.; Varakina, Y.; Vaselkina, E.; Kotsur, D.; Thomassen, Y. Essential and non-essential trace elements in fish consumed by indigenous peoples of the European Russian Arctic. Environ. Pollut. 2019, 253, 966-973. [CrossRef] [PubMed]

28. Zoroddu, M.A.; Aaseth, J.; Crisponi, G.; Medici, S.; Peana, M.; Nurchi, V.M. The essential metals for humans: A brief overview. J. Inorg. Biochem. 2019, 195, 120-129. [CrossRef] [PubMed]

29. Spalding, M.D.; Fox, H.E.; Allen, G.R.; Davidson, N.; Ferdaña, Z.A.; Finlayson, M.; Halpern, B.S.; Jorge, M.A.; Lombana, A.; Lourie, S.A.; et al. Marine ecoregions of the world: A bioregionalization of coastal and shelf areas. BioScience 2007, 57, 573-583. [CrossRef]

30. European Parliament; Council of the European Union. Directive 2002/32/EC of 7 May 2002 on Undesirable Substances in Animal Feed; Eur-Lex: Brussels, Belgium, 2002; Available online: https: / / eur-lex.europa.eu/legal-content/EN/TXT/?uri=CELEX\%3A32002L0 032 (accessed on 4 December 2020).

31. Pham, C.K.; Murillo, F.J.; Lirette, C.; Maldonado, M.; Colaço, A.; Ottaviani, D.; Kenchington, E. Removal of deep-sea sponges by bottom trawling in the Flemish Cap area: Conservation, ecology and economic assessment. Sci. Rep. 2019, 9, 1-13. [CrossRef]

32. Dyrynda, P.E.J. Defensive strategies of modular organisms. Philos. Trans. R. Soc. Lond. B Biol. Sci. 1986, 313, 227-243. [CrossRef]

33. Rius, M.; Branch, G.M.; Griffiths, C.L.; Turon, X. Larval settlement behaviour in six gregarious ascidians in relation to adult distribution. Mar. Ecol. Prog. Ser. 2010, 418, 151-163. [CrossRef]

34. Keen, S.L. Recruitment of Aurelia aurita (Cnidaria: Scyphozoa) larvae is position-dependent, and independent of conspecific density, within a settling surface. Mar. Ecol. Prog. Ser. 1987, 38, 151-160. [CrossRef]

35. Miranda, L.S.; Collins, A.G.; Marques, A.C. Molecules Clarify a Cnidarian Life Cycle-The "Hydrozoan" Microhydrula limopsicola Is an Early Life Stage of the Staurozoan Haliclystus antarcticus. PLoS ONE 2010, 5, e10182. [CrossRef]

36. Crisp, D.J.; Meadows, P.S. The chemical basis of gregariousness in cirripedes. Proc. R. Soc. Lond. B Biol. Sci. 1962, 156, 500-520. [CrossRef]

37. Burke, R.D. Pheromones and gregarious settlement of marine invertebrate larvae. Bull. Mar. Sci. 1986, 39, 323-331.

38. Millot, C.; Taupier-Letage, I. Circulation in the Mediterranean Sea. In The Mediterranean Sea; Springer: Berlin/Heidelberg, Germany, 2005; Volume 5K, pp. 29-66. [CrossRef] 
39. Bethoux, J.P.; Courau, P.; Nicolas, E.; Ruizpino, D. Trace-metal pollution in the Mediterranean Sea. Oceanol. Acta 1990, 13, 481-488.

40. Danovaro, R. Pollution threats in the Mediterranean Sea: An overview. Chem. Ecol. 2003, 19, 15-32. [CrossRef]

41. Tovar-Sánchez, A.; Rodríguez-Romero, A.; Engel, A.; Zäncker, B.; Fu, F.; Marañón, E.; Pérez-Lorenzo, M.; Bressac, M.; Wagener, T.; Triquet, S.; et al. Characterizing the surface microlayer in the Mediterranean Sea: Trace metal concentrations and microbial plankton abundance. Biogeosciences 2020, 17, 2349-2364. [CrossRef]

42. Adkins, J.F.; Henderson, G.M.; Wang, S.L.; O'Shea, S.; Mokadem, F. Growth rates of the deep-sea scleractinia Desmophyllum cristagalli and Enallopsammia rostrata. Earth Planet. Sci. Lett. 2004, 227, 481-490. [CrossRef]

43. Lough, J.M. Coral calcification from skeletal records revisited. Mar. Ecol. Prog. Ser. 2008, 373, 257-264. [CrossRef]

44. DeLong, K.L.; Quinn, T.M.; Taylor, F.W. Reconstructing twentieth-century sea surface temperature variability in the southwest Pacific: A replication study using multiple coral Sr/Ca records from New Caledonia. Paleoceanography 2007, 22, PA4212. [CrossRef]

45. Carilli, J.E.; Norris, R.D.; Black, B.; Walsh, S.M.; McField, M. Century-scale records of coral growth rates indicate that local stressors reduce coral thermal tolerance threshold. Glob. Change Biol. 2010, 16, 1247-1257. [CrossRef]

46. David, C.P. Heavy metal concentrations in growth bands of corals: A record of mine tailings input through time (Marinduque Island, Philippines). Mar. Pollut. Bull. 2003, 46, 187-196. [CrossRef]

47. Nour, H.E.S.; Nouh, E.S. Using coral skeletons for monitoring of heavy metals pollution in the Red Sea Coast, Egypt. Arab. J. Geosci. 2020, 13, 341. [CrossRef]

48. Readman, J.W.; Tolosa, I.; Law, A.T.; Bartocci, J.; Azemard, S.; Hamilton, T.; Mee, L.D.; Wagener, A.; Le Tissier, M.; Roberts, C.; et al. Discrete bands of petroleum hydrocarbons and molecular organic markers identified within massive coral skeletons. Mar. Pollut. Bull. 1996, 32, 437-443. [CrossRef]

49. Yang, T.; Diao, X.; Cheng, H.; Wang, H.; Zhou, H.; Zhao, H.; Chen, C.M. Comparative study of polycyclic aromatic hydrocarbons (PAHs) and heavy metals (HMs) in corals, sediments and seawater from coral reefs of Hainan, China. Environ. Pollut. 2020, 264, 114719. [CrossRef] [PubMed]

50. Sherwood, O.A.; Edinger, E.N. Ages and growth rates of some deep-sea gorgonian and antipatharian corals of Newfoundland and Labrador. Can. J. Fish. Aquat. Sci. 2009, 66, 142-152. [CrossRef]

51. Samperiz, A.; Robinson, L.F.; Stewart, J.A.; Strawson, I.; Leng, M.J.; Rosenheim, B.E.; Ciscato, E.R.; Hendry, K.R.; Santodomingo, N. Stylasterid corals: A new paleotemperature archive. Earth Planet. Sci. Lett. 2020, 545, 116407. [CrossRef]

52. Webster, N.S.; Webb, R.I.; Ridd, M.J.; Hill, R.T.; Negri, A.P. The effects of copper on the microbial community of a coral reef sponge. Environ. Microbiol. 2001, 3, 19-31. [CrossRef]

53. Mohanty, S.; Bapuji, M.; Mishra, R.K.; Sree, A.; Ray, P.; Mohapatra, S.B.; Rath, C.C. Studies on metal tolerance of bacterial associates of marine sedentary organisms. Asian J. Microbiol. Biotechnol. Environ. Sci. 2004, 6, 291-296.

54. Selvin, J.; Priya, S.S.; Kiran, G.S.; Bhosle, S. Biomonitoring of heavy metal pollution in the marine environment using indicator organisms. In Causes and Effects of Heavy Metal Pollution; Sánchez, M.L., Ed.; Nova Publishers: New York, NY, USA, 2008; Volume 4, pp. 251-264.

55. Selvin, J.; Priya, S.S.; Kiran, G.S.; Thangavelu, T.; Bai, N.S. Sponge-associated marine bacteria as indicators of heavy metal pollution. Microbiol. Res. 2009, 164, 352-363. [CrossRef]

56. Mangano, S.; Michaud, L.; Caruso, C.; Giudice, A.L. Metal and antibiotic resistance in psychrotrophic bacteria associated with the Antarctic sponge Hemigellius pilosus (Kirkpatrick, 1907). Polar Biol. 2014, 37, 227-235. [CrossRef]

57. Bauvais, C.; Zirah, S.; Piette, L.; Chaspoul, F.; Domart-Coulon, I.; Chapon, V.; Gallice, P.; Rebuffat, S.; Pérez, T.; BourguetKondracki, M.L. Sponging up metals: Bacteria associated with the marine sponge Spongia officinalis. Mar. Environ. Res. 2015, 104, 20-30. [CrossRef]

58. Karimi, E.; Gonçalves, J.M.; Reis, M.; Costa, R. Draft Genome Sequence of Microbacterium sp. Strain Alg239_V18, an Actinobacterium Retrieved from the Marine Sponge Spongia sp. Genome Announc. 2017, 5, e01457-16. [CrossRef]

59. Schmitt, S.; Wehrl, M.; Siegl, A.; Hentschel, U. Review article Marine sponges as models for commensal microbe-host interactions. Symbiosis 2007, 44, 43-50.

60. Santos-Gandelman, J.F.; Giambiagi-deMarval, M.; Oelemann, W.M.R.; Laport, M.S. Biotechnological potential of spongeassociated bacteria. In Current Pharmaceutical Biotechnology; Bentham Science Publishers: Valencia, Spain, 2014; Volume 15, pp. 143-155.

61. Thomas, T.; Moitinho-Silva, L.; Lurgi, M.; Björk, J.R.; Easson, C.; Astudillo-García, C.; Olson, J.B.; Erwin, P.M.; Lopez-Legentil, S.; Luter, H.; et al. Diversity, structure and convergent evolution of the global sponge microbiome. Nat. Commun. 2016, 7, 1-12. [CrossRef] [PubMed]

62. Jeanthon, C.; Prieur, D. Resistance to heavy metals of heterotrophic bacteria isolated from the deep-sea hydrothermal vent polychaete, Alvinella pompejana. Prog. Oceanogr. 1990, 24, 81-88. [CrossRef]

63. Prieur, D.; Chamroux, S.; Durand, P.; Erauso, G.; Fera, P.; Jeanthon, C.; Le Borgne, G.; Mével, G.; Vincent, P. Metabolic diversity in epibiotic microflora associated with the Pompeii worms Alvinella pompejana and A. caudata (Polychaetae: Annelida) from deep-sea hydrothermal vents. Mar. Biol. 1990, 106, 361-367. [CrossRef]

64. Rizzo, C.; Michaud, L.; Graziano, M.; De Domenico, E.; Syldatk, C.; Hausmann, R.; Giudice, A.L. Biosurfactant activity, heavy metal tolerance and characterization of Joostella strain A8 from the Mediterranean polychaete Megalomma claparedei (Gravier, 1906). Ecotoxicology 2015, 24, 1294-1304. [CrossRef] 
65. Ueki, T. Bioaccumulation of vanadium by vanadium-resistant bacteria isolated from the intestine of Ascidia sydneiensis samea. Mar. Biotechnol. 2016, 18, 359-371. [CrossRef]

66. Ueki, T.; Fujie, M.; Satoh, N. Symbiotic bacteria associated with ascidian vanadium accumulation identified by $16 \mathrm{~S}$ rRNA amplicon sequencing. Mar. Genom. 2019, 43, 33-42. [CrossRef]

67. Liberti, A.; Bertocci, I.; Pollet, A.; Musco, L.; Locascio, A.; Ristoratore, F.; Spagnuolo, A.; Sordino, P. An indoor study of the combined effect of industrial pollution and turbulence events on the gut environment in a marine invertebrate. Mar. Environ. Res. 2020, 158, 104950. [CrossRef]

68. Batel, R.; Bihari, N.; Rinkevich, B.; Dapper, J.; Schäcke, H.; Schröder, H.; Müller, W. Modulation of organotin-induced apoptosis by the water pollutant methyl mercury in a human lymphoblastoid tumor cell line and a marine sponge. Mar. Ecol. Prog. Ser. 1993, 93, 245-251. [CrossRef]

69. Jones, R.J. Testing the 'photoinhibition' model of coral bleaching using chemical inhibitors. Mar. Ecol. Prog. Ser. 2004, 284, 133-145. [CrossRef]

70. Lockyer, A.; Binet, M.T.; Styan, C.A. Importance of sperm density in assessing the toxicity of metals to the fertilization of broadcast spawners. Ecotoxicol. Environ. Saf. 2019, 172, 547-555. [CrossRef] [PubMed]

71. Lucas, C.H.; Horton, A.A. Short-term effects of the heavy metals, Silver and copper, on polyps of the common jellyfish, Aurelia aurita. J. Exp. Mar. Biol. Ecol. 2014, 461, 154-161. [CrossRef]

72. Duarte, C.M.; Pitt, K.A.; Lucas, C.H.; Purcell, J.E.; Uye, S.I.; Robinson, K.; Brotz, L.; Decker, M.B.; Sutherland, K.R.; Malej, A.; et al. Is global ocean sprawl a cause of jellyfish blooms? Front. Ecol. Environ. 2013, 11, 91-97. [CrossRef]

73. Purcell, J.E. Jellyfish and ctenophore blooms coincide with human proliferations and environmental perturbations. Ann. Rev. Mar. Sci. 2012, 4, 209-235. [CrossRef]

74. Purcell, J.E.; Uye, S.I.; Lo, W.T. Anthropogenic causes of jellyfish blooms and their direct consequences for humans: A review. Mar. Ecol. Prog. Ser. 2007, 350, 153-174. [CrossRef]

75. Viarengo, A.; Burlando, B.; Giordana, A.; Bolognesi, C.; Gabrielides, G.P. Networking and expert-system analysis: Next frontier in biomonitoring. Mar. Environ. Res. 2000, 49, 483-486. [CrossRef]

76. Agell, G.; Uriz, M.J.; Cebrian, E.; Martí, R. Does stress protein induction by copper modify natural toxicity in sponges? Environ. Toxicol. Chem. Int. J. 2001, 20, 2588-2593. [CrossRef]

77. Berthet, B.; Mouneyrac, C.; Pérez, T.; Amiard-Triquet, C. Metallothionein concentration in sponges (Spongia officinalis) as a biomarker of metal contamination. Comp. Biochem. Phys. C Toxicol. Pharmacol. 2005, 141, 306-313. [CrossRef]

78. Amiard, J.C.; Amiard-Triquet, C.; Barka, S.; Pellerin, J.; Rainbow, P.S. Metallothioneins in aquatic invertebrates: Their role in metal detoxification and their use as biomarkers. Aquat. Toxicol. 2006, 76, 160-202. [CrossRef]

79. Franchi, N.; Boldrin, F.; Ballarin, L.; Piccinni, E. CiMT-1, an unusual chordate metallothionein gene in Ciona intestinalis genome: Structure and expression studies. J. Exp. Zool. A Ecol. Genet. Physiol. 2011, 315, 90-100. [CrossRef]

80. Zanette, J.; Monserrat, J.M.; Bianchini, A. Biochemical biomarkers in barnacles Balanus improvisus: Pollution and seasonal effects. Mar. Environ. Res. 2015, 103, 74-79. [CrossRef] [PubMed]

81. Karntanut, W.; Pascoe, D. The toxicity of copper, cadmium and zinc to four different Hydra (Cnidaria: Hydrozoa). Chemosphere 2002, 47, 1059-1064. [CrossRef]

82. Piola, R.F.; Johnston, E.L. Differential tolerance to metals among populations of the introduced bryozoan Bugula neritina. Mar. Biol. 2006, 148, 997-1010. [CrossRef]

83. Capdevila, M.; Atrian, S. Metallothionein protein evolution: A miniassay. J. Biol. Inorg. Chem. 2011, 16, 977-989. [CrossRef]

84. Casado-Martinez, M.C.; Smith, B.D.; Luoma, S.N.; Rainbow, P.S. Metal toxicity in a sediment-dwelling polychaete: Threshold body concentrations or overwhelming accumulation rates? Environ. Pollut. 2010, 158, 3071-3076. [CrossRef]

85. Domingos, R.F.; Gélabert, A.; Carreira, S.; Cordeiro, A.; Sivry, Y.; Benedetti, M.F. Metals in the aquatic environment-Interactions and implications for the speciation and bioavailability: A critical overview. Aquat. Geochem. 2015, 21, 231-257. [CrossRef]

86. Goldberg, E.D.; Bowen, V.T.; Farrington, J.W.; Harvey, G.; Martin, J.H.; Parker, P.L.; Risebrough, R.W.; Robertson, W.; Schneider, E.; Gamble, E. The Mussel Watch. In Environmental Conservation; The Foundation of Environmental Conservation: La Jolla, CA, USA, 1978; Volume 5, pp. 101-105.

87. Roose, P.; Albaigés, J.; Bebianno, M.J.; Camphuysen, C.; Cronin, M.; de Leeuw, J.; Gabrielsen, G.; Hutchinson, T.; Hylland, K.; Jansson, B.; et al. Chemical Pollution in Europe's Seas: Programmes, Practices and Priorities for Research; Marine Board Position Paper, 16; Calewaert, J.B., McDonough, N., Eds.; Marine Board-ESF: Ostend, Belgium, 2011.

88. Gabrielides, G. MED POL Biomonitoring Programme Concerning the Effects of Pollutants on Marine Organisms along the Mediterranean Coasts; UNEP(OCA)/MED WG 132/3; Athens: Athens, Greece, 1997.

89. Da Silva, M.; Passarini, M.R.Z.; Bonugli, R.C.; Sette, L.D. Cnidarian-derived filamentous fungi from Brazil: Isolation, characterisation and RBBR decolourisation screening. Environ. Technol. 2008, 29, 1331-1339. [CrossRef]

90. Rosa, I.C.; Costa, R.; Gonçalves, F.; Pereira, J.L. Bioremediation of Metal-Rich Effluents: Could the Invasive Bivalve Corbicula fluminea Work as a Biofilter? J. Environ. Qual. 2014, 43, 1536-1545. [CrossRef]

91. Tamilselvi, M.; Akram, A.S.; Arshan, M.K.; Sivakumar, V. Comparative study on bioremediation of heavy metals by solitary ascidian, Phallusia nigra, between Thoothukudi and Vizhinjam ports of India. Ecotoxicol. Environ. Saf. 2015, 121, 93-99. [CrossRef] 
92. Sicuro, B.; Castelar, B.; Mugetti, D.; Pastorino, P.; Chiarandon, A.; Menconi, V.; Galloni, M.; Prearo, M. Bioremediation with freshwater bivalves: A sustainable approach to reducing the environmental impact of inland trout farms. J. Environ. Manag. 2020, 276, 111327. [CrossRef]

93. Relini, G.; Giaccone, G. Priority habitats according to the SPA/BIO protocol (Barcelona Convention) present in Italy. Identification sheets. Biol. Mar. Mediterr. 2009, 16 (Suppl. 2), 435p. 